\title{
Adenosine Deaminase
}

National Cancer Institute

\section{Source}

National Cancer Institute. Adenosine Deaminase. NCI Thesaurus. Code C16261.

Adenosine deaminase (363 aa, $\sim 41 \mathrm{kDa}$ ) is encoded by the human ADA gene. This protein plays a role in purine metabolism. 